\title{
Idioblasts formation and essential oil production in irrigated Piper aduncum ${ }^{1}$
}

\author{
Ana Carolina Pires Jacinto 2 , Leonardo Paula de Souza ${ }^{3}$, \\ Adriana Tiemi Nakamura ${ }^{2}$, Fábio Janoni Carvalho ${ }^{4}$, Edson Simão ${ }^{2}$, João Luis Zocoler ${ }^{5}$, Celso Luis Bergo ${ }^{6}$
}

\begin{abstract}
The growing of Piper aduncum for essential oil extraction has increased, but there is a lack of basic information about its management and cultivation, which allows the productivity and quality of the oil, in order to attend the market demands. This study aimed to evaluate the relation between the production of essential oils from $P$. aduncum and soil water pressure heads $(20 \mathrm{kPa}, 40 \mathrm{kPa}, 60 \mathrm{kPa}, 100 \mathrm{kPa}$ and non-irrigated). The assessment comprised the quantification of idioblasts and the production of essential oil extracted from leaves of cultivated plants. The variation in the soil water pressure head alters the amount of idioblasts in P. aduncum leaves, with impacts on the essential oil production. A soil water pressure head range of $20-60 \mathrm{kPa}$ is sufficient for this species to express the highest amount of idioblasts and the highest level of essential oil production. The species adapts itself to different water availability conditions in the soil. Under stress conditions, due to water deficit or excess, the production of essential oil is reduced.
\end{abstract}

KEYWORDS: Piperaceae; water stress; oil cells.

\section{INTRODUCTION}

Piperaceae is comprised of five genera, and around 3,615 species spread throughout tropical areas (Quijano-Abril et al. 2008, Melo et al. 2016). Several of these species present properties suitable for pharmacological and chemical uses, such as Piper aduncum L., popularly known as "pimenta-demacaco" in Brazil and exploited commercially for the

\section{RESUMO}

Formação de idioblastos e produção de óleo essencial em cultivo irrigado de Piper aduncum

O cultivo de Piper aduncum para a extração de óleo essencial é crescente, mas carece de informações básicas de manejo e cultivo, que possibilitem produtividade e qualidade do produto para atender a demanda de mercado. Objetivou-se avaliar a relação entre a produção de óleos essenciais em $P$. aduncum e tensões de água no solo (20 kPa, $40 \mathrm{kPa}, 60 \mathrm{kPa}, 100 \mathrm{kPa}$ e sem irrigação). Foram avaliados o número de idioblastos e a produção de óleo essencial em folhas de plantas cultivadas. A variação na tensão de água no solo altera a quantidade de idioblastos nas folhas de P. aduncum, com reflexo na produção de óleo essencial. A tensão de água no solo de 20-60 kPa é suficiente para a planta expressar o maior número de idioblastos e maior produção de óleo essencial. A espécie se adapta a diferentes condições de disponibilidade de água no solo. Em condições de estresse, devido ao déficit ou excesso de água, a produção de óleo essencial é reduzida.

PALAVRAS-CHAVE: Piperaceae; estresse hídrico; células oleíferas.

production of monoterpene (Taiz et al. 2017), which is basically an essential oil from which the dillapiole phenyl ether is extracted (Siviero et al. 2015).

The species is common in the Amazon and Atlantic Forest biomes, as well as in humid areas of the Brazilian Savannah. Less frequently, it may also be found in anthropized environments (Ribeiro et al. 1999), which preserve mild conditions of luminosity and higher water availability. Its commercial

1. Received: May 25, 2018. Accepted: Oct. 10, 2018. Published: Dec. 12, 2018. DOI: 10.1590/1983-40632018v4853165.

2. Universidade Federal de Uberlândia, Instituto de Ciências Agrárias, Monte Carmelo, MG, Brasil. E-mail/ORCID: carol.agro.ufu@gmail.com/0000-0001-8184-5803, atnakamura@ufu.br/0000-0002-8527-8962, esimao@ufu.br/0000-0001-8855-2907.

3. Universidade Federal do Acre, Centro de Ciências Biológicas e da Natureza, Rio Branco, AC, Brasil. E-mail/ORCID: leonardo.acre@gmail.com/0000-0002-4522-8020.

4. Instituto Federal de Educação, Ciência e Tecnologia do Triângulo Mineiro, Uberaba, MG, Brasil. E-mail/ORCID: fabiojanoni@iftm.edu.br/0000-0002-0327-1821.

5. Universidade Estadual Paulista Júlio de Mesquita Filho, Faculdade de Engenharia de Ilha Solteira, Departamento de Fitossanidade, Engenharia Rural e Solos, Ilha Solteira, SP, Brasil. E-mail/ORCID: jlzocoler@gmail.com/0000-0001-5038-7715. 6. Empresa Brasileira de Pesquisa Agropecuária (Embrapa Acre), Centro de Pesquisa Agroflorestal, Rio Branco, AC, Brasil. E-mail/ORCID: celso.bergo@embrapa.br/0000-0003-1902-8188. 
exploitation results from the experimental planting and management of native populations.

The essential oil production is related to the presence of secretory structures, such as idioblasts and secretory trichomes (Silva \& Machado 1999, Marinho et al. 2011, Tozin et al. 2015). Idioblasts are present in all parts of $P$. aduncum plants, mostly in the leaves (Lakshmia \& Naidu 2010, Marinho et al. 2011, Gogosz et al. 2012, Nakamura et al. 2015, Santos et al. 2018), which are the source for the highest amounts of essential oil. These secondary metabolism compounds are targeted by the chemical industry and present multiple biological effects exploited as insecticides, fungicides, molluscicides, acaricides, bactericides and larvicides, with the advantage of being biodegradable products (Zacaroni et al. 2009, Costa et al. 2010, Pino et al. 2011, Piton et al. 2014, Rapado et al. 2014, Santos \& Siviero 2015, Pinto et al. 2016).

Secondary metabolism compounds are related to defense mechanisms against herbivores, pathogens and other abiotic stress factors. These stress factors may change the plant metabolism, favoring the production of compounds related to osmotic adjustment, free radical and toxic elements depletion or protection against herbivores and pathogens (Taiz et al. 2017). In this regard, there is a lack of studies and data to correlate the development of structures such as idioblasts and secondary metabolism compounds produced in response to stress caused by the modification of light conditions, air temperature, water availability in the soil and nutrients. The strongest evidences depict the interactions between the production of secondary metabolism compounds and abiotic factors.

As for the Piper genus, Silva et al. (2009), after studying $P$. hispidinervum, report that, when irrigation takes place, an increment of leaves and fine branches is observed up to the seventh month after planting, and, after that, an increment of dry matter in the main stem prevails. Besides, the authors claim that the water supplementation leads the plants to a higher primary productivity, as demonstrated by the biomass production and consequent higher amount of essential oil produced by the species, which, according to Rocha Neto et al. (2005), does not tolerate prolonged droughts. Nevertheless, there is no substantial data available on the effect of water restriction over the essential oil production from Piper sp.
In an attempt to fulfill this gap, this study aimed to assess the relation between the essential oil production from $P$. aduncum leaves and water availability conditions in the soil for its cultivation, by means of determining the amount of idioblasts and essential oil production.

\section{MATERIAL AND METHODS}

The $P$. aduncum specimens used in this experiment were cultivated at the Embrapa Acre, in Rio Branco, Acre State, Brazil, from July 2015 to July 2016. The collected plants were grown under a dripping irrigation system with different soil water pressure head settings (Souza 2016).

A randomized block design was used, with five treatments (soil water pressure heads of $20 \mathrm{kPa}$, $40 \mathrm{kPa}, 60 \mathrm{kPa}$ and $100 \mathrm{kPa}$ and non-irrigation) and four replications. These soil water pressure head levels were chosen for the plant to demonstrate its vegetative and productive development in different water availabilities in the soil. As the soil dries, the water absorption becomes more difficult, because retention forces increase and water availability in the soil decreases (Reichardt \& Timm 2004). This may cause a severe wilting process in the plants and, later, the fall of the leaves. The irrigation started when the soil reached the stipulated soil water pressure heads for each treatment.

With these soil water pressure heads, the plants were grown under favorable and unfavorable conditions of soil water uptake. A soil water pressure head of $10-20 \mathrm{kPa}$ indicates that the soil water content is in the field capacity or near it (Pereira et al. 2006). A suitable soil water content is found at 40-60 kPa, which has a good availability of water and air (Marouelli et al. 2011). On the other hand, for a soil water pressure head above $60 \mathrm{kPa}$, the soil water content conditions may affect the potential evapotranspiration (Marouelli 2008).

The soil of the experimental area was classified as a Red Oxisol (Santos et al. 2013). Two soil samples were collected in the middle layer $(0-0.25 \mathrm{~m}$ depth) and sent to physical and chemical analysis. The soil physical analysis indicated $51 \%$ of silt, $31 \%$ of clay, $16 \%$ of fine sand and $2 \%$ of coarse sand, with a medium texture. The soil presented the following chemical characteristics: $\mathrm{pH}=5.64$ $\mathrm{Ca}=3.50 \mathrm{cmol} \mathrm{dm}^{-3} ; \mathrm{Mg}=1.05 \mathrm{cmol} \mathrm{dm}^{-3}$; $\mathrm{K}=0.20 \mathrm{cmol}_{\mathrm{c}} \mathrm{dm}^{-3} ; \mathrm{H}+\mathrm{Al}=2.37 \mathrm{cmol}_{\mathrm{c}} \mathrm{dm}^{-3}$; 
$\mathrm{P}=0.48 \mathrm{mg} \mathrm{dm}^{-3}$; sum of bases $=4.75 \mathrm{cmol}_{\mathrm{c}} \mathrm{dm}^{-3}$; cation exchange capacity $=7.12 \mathrm{cmol}_{\mathrm{c}} \mathrm{dm}^{-3}$; base saturation $=66.71 \%$ and organic matter $=9.53 \mathrm{~g} \mathrm{~kg}^{-1}$.

At the same soil depth, soil and water samples were also collected and sent to the laboratory. To obtain the soil-water retention data, two samples were submitted to a standard laboratory methodology with suction funnels and pressure plates, using soil water pressure heads of $1 \mathrm{kPa}, 3 \mathrm{kPa}, 10 \mathrm{kPa}, 30 \mathrm{kPa}$, $50 \mathrm{kPa}, 100 \mathrm{kPa}$ and $1,500 \mathrm{kPa}$. The Van Genuchten (1980) equation was fitted to these data, resulting in a $\mathrm{R}^{2}>0.981$ (Dourado Neto et al. 1990). The equation was adjusted as it follows: $\theta=0.129+0.242 /[1+$ $\left.\left(0.2857^{*} \mathrm{~h}\right)^{\wedge} 1.5746\right]^{\wedge} 0.3649$, where $\theta$ is the soil moisture $\left(\mathrm{cm}^{3} \mathrm{~cm}^{-3}\right)$ and $h$ the soil water pressure head $(\mathrm{kPa})$. The field capacity has a soil water pressure head of 6-30 kPa (Carvalho \& Oliveira 2012). For field capacity, the soil water pressure head equivalent to $10 \mathrm{kPa}$ was adopted. With this soil water pressure head, the soil moisture was $0.253 \mathrm{~cm}^{3} \mathrm{~cm}^{-3}$, estimated by the aforementioned equation. Based on this equation and the observed values, the water retention curve in the soil was generated for the layer under study (Figure 1).

A puncture tensiometer was used to measure the soil water pressure head $(20-60 \mathrm{kPa})$ and electric resistance sensors for measuring the $100 \mathrm{kPa}$ soil water pressure head, installed at a $0.25 \mathrm{~m}$ depth. For the non-irrigated treatment, there was no soil water pressure head assessment. The drip irrigation system used auto-compensating emitters with an outflow of $10 \mathrm{~L} \mathrm{~h}^{-1}$ (Souza 2016). The treatment differentiation and water management by drip irrigation corresponded to a period of 125 consecutive

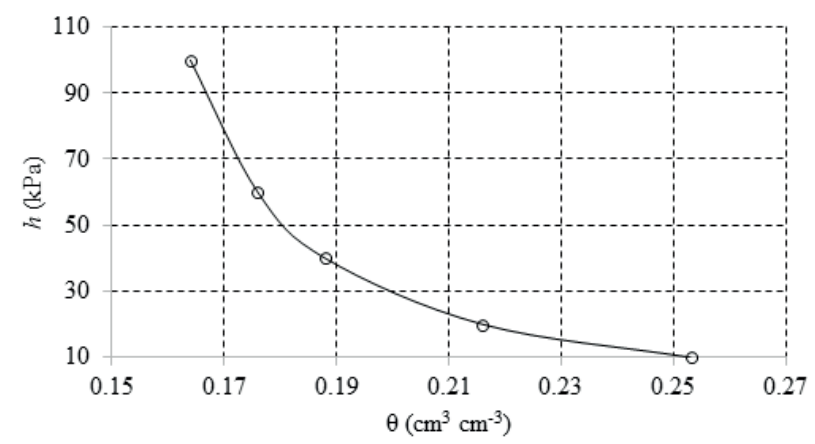

Figure 1. Water retention curve in the soil (0-0.25 m depth) generated using the model proposed by Van Genutchen (1980), where $\theta$ is the soil moisture and $h$ the soil water pressure head. days after the transplant, and the irrigation was discontinued due to the beginning of the rainy season in the Rio Branco region. At that time, the plant shoot was cut for biomass quantification and, consequently, essential oil extraction, at eleven months after planting.

The collection of leaf samples was carried out for morphologic analysis at 255 days after the cultivation, and irrigation was performed during a four-month period (June to September 2015), according to the established treatments. For the analysis, samples from the median part of the leaf blade on the third node were collected after fully expanding the leaves, and four plants per treatment were evaluated.

The leaf samples were fixed in a Karnovsky solution (Karnovsky 1965) and dehydrated in an alcohol series, then infiltrated, included in hydroxyethyl methacrylate (Feder \& O'Brien 1968) and cut into histological sections of $5 \mu \mathrm{m}$ thick, with a rotation microtome. The microscope slides were stained using Toluidine Blue O (O’Brien et al. 1965).

Five microscope slides with five cross sections of each foliar sample were prepared, for a total of 100 observations per treatment. The amount of idioblasts per $\mathrm{mm}^{2}$ was counted in each microscope slide section from each sample obtained from the leaves. The Image JT ${ }^{\mathrm{TM}}$ software was used for the quantification of idioblasts.

The essential oil was extracted by the condensed water recirculation method (Heath 1977). In the extraction process, $25 \mathrm{~g}$ of dry biomass collected from two plants of the useful plot in the four repetitions per treatment were used, according to the protocol established by Negreiros \& Miqueloni (2013), modified by Souza (2016). After measuring the weight, the samples were mixed to $450 \mathrm{~mL}$ of distilled water and then boiled to the temperature of $100{ }^{\circ} \mathrm{C}$, in a heating mantle, for $60 \mathrm{~min}$, to obtain the dry biomass. After this period, the denser fraction with the oil was collected and later quantified in a HP gas chromatograph (model 6890), where helium was used as the dragging gas.

The resulting data were statistically evaluated by analysis of variance (Anova), after checking the assumptions of normality of residuals with the Shapiro-Wilk test; variance homogeneity with the Levene test; and additivity of blocks with the Tukey test. These assumptions must be attended to avoid the error types I and II in the Anova. Significant 
variables were adjusted to regression models. All tests were carried out with a statistical significance level of $5 \%(p \leq 0.05)$.

\section{RESULTS AND DISCUSSION}

Both variables attended the assumptions of normality for residuals, variance homogeneity and additivity of blocks ( $\mathrm{p} \geq 0.05$ ), and Anova was performed.

The amount of idioblasts per $\mathrm{mm}^{2}$ varied among the different water soil pressure heads (Figure 2). It is possible to verify that, for the 20-40 kPa soil water pressure head range, the amount of idioblasts practically did not change. Nevertheless, for $40-50 \mathrm{kPa}$, an average increase of $33 \%$ in the amount of idioblasts occurred, reaching its peak at $60 \mathrm{kPa}$. For $60-100 \mathrm{kPa}$, the amount of idioblasts was reduced by $21 \%$, indicating that the plant struggled to extract water from the soil, with a consequent decrease in the amount of idioblasts.

The lowest amount of idioblasts was observed for the non-irrigated setting (97). In comparison to the amount of idioblasts obtained at $60 \mathrm{kPa}$, which is the treatment where the highest amount of idioblasts was observed, there was an average reduction of $49 \%$. Therefore, it is possible to infer that the lowest idioblast averages were observed in plants grown in soils that were close to the field capacity, as well as in the non-irrigated ones. However, the amount of idioblasts (Figure 2) and the essential oil production were altered in extreme ranges of less water availability and water excess in the soil.

The soil water pressure head of $60 \mathrm{kPa}$ resulted in the greatest observed amount of idioblasts (Figure 2). For the 20-60 kPa range, the highest

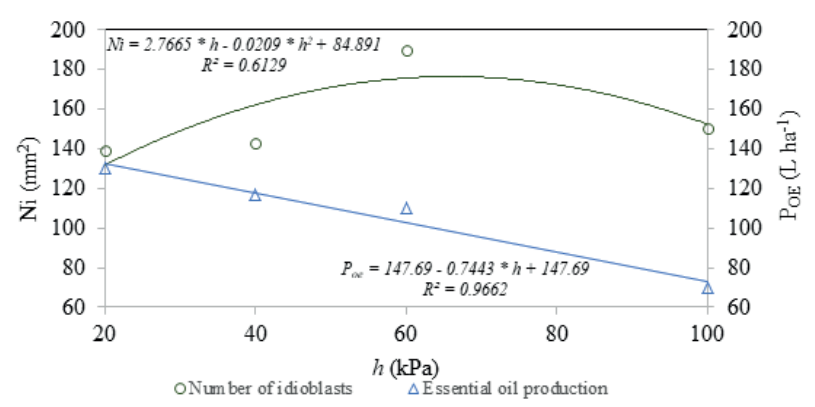

Figure 2. Number of Piper aduncum idioblasts (Ni) and essential oil production $\left(\mathrm{P}_{\mathrm{OE}}\right)$, as a function of the soil water pressure head (h). increase in the amount of fresh and dry biomass was noticed (Souza 2016), reflecting a more favorable setting for plant development.

Moreover, the outcome of essential oil productivity (Figure 2) follows the same tendency, correlating with the highest increase in biomass. In the non-irrigated setting, the essential oil productivity was $50 \mathrm{~L} \mathrm{ha}^{-1}$, i.e., an average reduction of $61.5 \%$, in relation to the more productive setting of $20 \mathrm{kPa}$ (130 L ha') (Souza 2016).

The higher number of idioblasts and content of essential oils observed in the treatments with a greater availability of water in the soil suggest that they are not related to water stress. Although the monoterpenoids may be connected to water stress or defense mechanisms against herbivory and pathogens (Bohnert et al. 1995, Taiz et al. 2017), in the present study, we believe that these compounds are involved in the plant defense.

When subjecting the plant to stressful conditions that limit its development, the resources intended to the growth of idioblasts and the production of essential oils are channeled into other forms of adjustment and adaptation, for example, the production of free proline for osmotic cell adjustment (Bohnert et al. 1995, Alvarenga et al. 2011, Krishania et al. 2013). Furthermore, as water availability in the soil becomes restricted, the amount of idioblasts does not imply a higher essential oil production(Figure 2). This behavior represents a morphological adjustment attributed to the decrease of idioblasts with an increasing water restriction, and the sparing of resources to produce organic substances for osmotic adaptation, stomatal movement regulation and depletion of free radicals (Taiz et al. 2017). The results reflect the species phenotypic plasticity to stress, when growing under different water soil availability conditions.

Therefore, a higher amount of idioblasts does not necessarily lead to an increase in oil production, for the plant may compensate the lesser amount of idioblasts by increasing its biomass or by concentrating the essential oil stored in its idioblasts. Besides, the excess of water apparently affects the plant physiology and diminishes its essential oil production in the range of $0.744 \mathrm{~L}$ per soil water pressure head unit increase (Souza 2016). These results support the concept that both abundance and deprivation of water may be stressful situations for the plant (Taiz et al. 2017). Nonetheless, the physiological adjustment in each setting tends to 
be different. As far as the idioblast production is concerned, when the plant is under moderate stress it increases, and under more severe conditions there is a channeling of the plant energy into developing other ways of adapting, like the production of free proline for osmotic cell adjustment (Bohnert et al. 1995, Alvarenga et al. 2011). That being the case, further research and studies regarding phenotypic plasticity and physiological responses of Piper sp. species, when cultivated under environments different from the natural one, are necessary.

\section{CONCLUSIONS}

1. The variation in the soil water pressure head differently alters the idioblasts amount in Piper aduncum leaves and the essential oil production;

2. A higher production of essential oil by $P$. aduncum is correlated with the water soil availability, and not necessarily linked to the amount of idioblasts;

3. The amount of idioblasts and the content of essential oil are not related to the adaptation to water stress conditions. This may be connected to defense mechanism purposes against herbivory and pathogens;

4. The adequate soil water pressure head range to define the beginning of crop irrigation is $20-60 \mathrm{kPa}$, which reflects a peak amount of idioblasts.

\section{ACKNOWLEDGMENTS}

The authors thank the Conselho Nacional de Desenvolvimento Científico e Tecnológico (CNPq) for funding this project (process number 454046/2014-6) and granting a scholarship to the first author (PIBIC-UFUCNPq process number 2015-AGR034).

\section{REFERENCES}

ALVARENGA, I. C. A. et al. Prolina livre em alecrimpimenta sob estresse hídrico antes da colheita. Revista Brasileira de Plantas Medicinais, v. 13, n. esp., p. 539541, 2011.

BOHNERT, H. J.; NELSON, D. E.; JENSEN, R. G. Adaptations to environmental stresses. The Plant Cell, v. 7, n. 7, p. 1099-1111, 1995.

CARVALHO, D. F.; OLIVEIRA, L. F. C. Planejamento e manejo da água na agricultura irrigada. Viçosa: Ed. UFV, 2012.
COSTA, J. G. M. da et al. Composição química e toxicidade de óleos essenciais de espécies de Piper frente a larvas de Aedes aegypti L. (Diptera: Culicidae). Latin American Journal of Pharmacy, v. 29, n. 3, p. 463-467, 2010.

DOURADO NETO, D. et al. Programa para confecção da curva de retenção de água no solo utilizando o modelo de van Genuchten. Engenharia Rural, v. 1, n. 2, p. 92-102, 1990.

FEDER, N.; O'BRIEN, T. P. Plant microtechnique: some principles and new methods. American Journal of Botany, v. 55, n. 1, p. 123-142, 1968.

GENUCHTEN, M. T. V. A closed-form equation for predicting the hydraulic conductivity of unsaturated soils. Soil Science Society of America Journal, v. 44, n. 5, p. 892-898, 1980.

GOGOSZ, A. M. et al. Anatomia foliar comparativa de nove espécies do gênero Piper (Piperaceae). Rodriguésia, v. 63, n. 2, p. 405-417, 2012.

HEATH, H. B. Flavorings, condiments and relishes. In: DESROSIER, N. W. (Ed.). Elements of food technology. Wesrport: The Avipublishing Company, 1977. p. 666701.

KARNOVSKY, M. J. A formaldehyde-glutaraldehyde fixative of high osmolality for use in electronmicroscopy. Journal of Cell Biology, v. 27, n. 2, p. 137-138, 1965.

KRISHANIA, S.; DWIVEDI, P.; AGARWAL, K. Strategies of adaptation and injury exhibited by plants under a variety of external conditions: a short review. Comunicata Scientiae, v. 4, n. 2, p. 103-110, 2013.

LAKSHMIA, B. S.; NAIDU, K. C. Comparative morphoanatomy of Piper betle L. cultivars in India. Annals of Biological Research, v. 1, n. 2, p. 128-134, 2010.

MARINHO, C. R.; ZACARO, A. A.; VENTRELLA, M. C. Secretory cells in Piper umbellatum (Piperaceae) leaves: a new example for the development of idioblasts. Flora, v. 206, n. 12, p. 1052-1062, 2011.

MAROUELLI, W. A. et al. Manejo da água de irrigação. In: SOUSA, V. F. Irrigação e fertirrigação em fruteiras e hortaliças. Brasília, DF: Embrapa, 2011. p. 159-232.

MAROUELLI, W. A. Tensiômetros para o controle de irrigação em hortaliças. Brasília, DF: Embrapa-CNPH, 2008.

MELO, A.; GUIMARÃES, A. F.; ALVES, M. Synopsis of the genus Peperomia Ruiz \& Pav. (Piperaceae) in Roraima state, Brazil. Hoehnea, v. 43, n. 1, p. 119-134, 2016.

NAKAMURA, A. T. et al. Origin of the subepidermal tissue in Piper L. leaves. Brazilian Journal of Biology, v. 75 , n. 2 , p. $368-371,2015$. 
NEGREIROS, J. R. S.; MIQUELONI, D. P. Teor de dilapiol em função do tipo de biomassa aérea em populações de Piper aduncum. Revista de Ciências Agrárias, v. 56, n. 1, p. 73-79, 2013.

O'BRIEN, T. P.; FEDER, N.; MCCULLY, M. E. Polychromatic staining of plant cell walls by toluidine blue O. Protoplasma, v. 59, n. 2, p. 368-373, 1965.

PEREIRA, A. B. et al. Monitoramento da irrigação por meio da tensão da água no solo. Ponta Grossa: Ed. UEPG, 2006.

PINO, O. et al. Caracterización química y actividad acaricida del aceite esencial de Piper aduncum subsp. ossanum frente a Varroa destructor. Revista de Protección Vegetal, v. 26, n. 1, p. 52-61, 2011.

PINTO, E. G.; LANA, A. J. D.; LIMA, R. A. Estudo fitoquímico do extrato etanólico de Piper tuberculatum Jacq. sobre cepas de Escherichia coli in vitro. South American Journal of Basic Education, Technical and Tecnological, v. 3, n. 2, p. 27-36, 2016.

PITON, L. P. et al. Natural insecticide based-leaves extract of Piper aduncum (Piperaceae) in the control of stink bug brown soybean. Ciência Rural, v. 44, n. 11, p. 1915-1920, 2014.

QUIJANO-ABRIL, M. A.; CALLEJAS-POSADA, R.; MIRANDA-ESQUIVEL, D. R. Areas of endemism and distribution patterns for neotropical Piper species (Piperaceae). Journal of Biogeography, v. 33, n. 7, p. 12661278, 2006.

RAPADO, L. N. et al. A benzoic acid derivative and flavokawains from Piper species as schistosomiasis vector controls. Molecules, v. 19, n. 4, p. 5205-5218, 2014.

REICHARDT, K.; TIMM, L. C. Solo, planta e atmosfera: conceitos, processos e aplicações. Barueri: Manole, 2004.

RIBEIRO, J. E. L. da S. et al. Flora da reserva Ducke: guia de identificação das plantas vasculares de uma floresta de terra firme na Amazônia Central. Manaus: INPA, 1999.
ROCHA NETO, O. G. da et al. Recomendações para o cultivo da pimenta longa (Piper hispidinervium C. DC.) no estado do Pará. Belém: Embrapa-CPATU/PA, 2005.

SANTOS, H. G. dos et al. Sistema brasileiro de classificação de solos. 3. ed. Brasília, DF: Embrapa, 2013.

SANTOS, V. L. P. dos et al. Anatomy and microscopy of Piper caldense, a folk medicinal plant from Brazil. Revista Brasileira de Farmacognosia, v. 28, n. 1, p. 9-15, 2018.

SILVA, E. S. A. Parâmetros bioquímicos de plantas de pimenta longa (Piper hispidinervum C.DC.) em diferentes condições de cultivo no município de Igarapé-Açu, PA. Revista Ciências Agrárias, v. 1, n. 51, p. 171-189, 2009.

SILVA, E. M. J.; MACHADO, S. M. Ultrastructure and cytochemistry of the pearl gland in Piper regnellii (Piperaceae). Nordic Journal of Botany, v. 19, n. 5, p. 623634, 1999.

SIVIERO, A. et al. A contribuição de espécies do gênero Piper para a agroecologia no Acre. In: SANTOS, R. C.; SIVIERO, A. Agroecologia no Acre. Rio Branco: IFAC, 2015. p. 305-356.

SOUZA, L. P. Manejo da irrigação na cultura Piper aduncum L. 2016. 67 f. Tese (Doutorado em Agronomia) Universidade Estadual Paulista, Botucatu, 2016.

TAIZ, L. et al. Fisiologia e desenvolvimento vegetal. 6. ed. Porto Alegre: Artmed, 2017.

TOZIN, L. R. S.; MARQUES, M. O. M.; RODRIGUES, T. M. Glandular trichome density and essential oil composition in leaves and inflorescences of Lippia origanoides Kunth. (Verbenaceae) in the Brazilian Cerrado. Anais da Academia Brasileira de Ciências, v. 87, n. 2, p. 943-953, 2015.

ZACARONI, L. M. et al. Potencial fungitóxico do óleo essencial de Piper hispidinervum (pimenta longa) sobre os fungos fitopatogênicos Bipolaris sorokiniana, Fusarium oxysporum e Colletotrichum gloeosporioides. Acta Amazonica, v. 39, n. 1, p. 193-198, 2009. 